\title{
Review \\ Molecular Biology of Pediatric and Adult Male Germ Cell Tumors
}

\author{
Mariana Tomazini Pinto ${ }^{1,2,+}$, Flavio Mavignier Cárcano ${ }^{1,3,4,+}$, Ana Glenda Santarosa Vieira ${ }^{2,5}$, \\ Eduardo Ramos Martins Cabral ${ }^{1}$ and Luiz Fernando Lopes ${ }^{2,5, *}$
}

check for

updates

Citation: Pinto, M.T.; Cárcano, F.M.; Vieira, A.G.S.; Cabral, E.R.M.; Lopes, L.F. Molecular Biology of Pediatric and Adult Male Germ Cell Tumors. Cancers 2021, 13, 2349. https:// doi.org/10.3390/cancers13102349

Academic Editor: Samuel Mok

Received: 15 February 2021

Accepted: 12 April 2021

Published: 13 May 2021

Publisher's Note: MDPI stays neutral with regard to jurisdictional claims in published maps and institutional affiliations.

Copyright: (c) 2021 by the authors. Licensee MDPI, Basel, Switzerland. This article is an open access article distributed under the terms and conditions of the Creative Commons Attribution (CC BY) license (https:// creativecommons.org/licenses/by/ $4.0 /)$.
1 Molecular Oncology Research Center, Barretos Cancer Hospital, Barretos 14784400, Brazil; mariana.tomazini@hcancerbarretos.com.br (M.T.P.); carcano.fm@facisb.edu.br (F.M.C.); eduardo.cabral@hospitaldeamor.com.br (E.R.M.C.)

2 Brazilian Childhood Germ Cell Tumor Study Group, The Brazilian Pediatric Oncology Society (SOBOPE), Barretos 14784400, Brazil; anaglenda.santarosa@hospitaldeamor.com.br

3 Department of Clinical Oncology, Barretos Cancer Hospital, Barretos 14784400, Brazil

4 Barretos School of Health Sciences Dr. Paulo Prata-FACISB, Barretos 14785002, Brazil

5 Barretos Children's Cancer Hospital from Hospital de Amor, Barretos 14784400, Brazil

* Correspondence: lf.lopes@hcbinfantil.com.br; Tel.: +55-17-3321-6600

+ These authors contributed equally to this manuscript.

Simple Summary: Although testicular germ cell tumors (TGCTs) are rare pediatric malignancies, they are the most common malignancies in young adult men. The similarities and differences between TGCTs in adults and children, taking into account the clinic presentation, biology, and molecular changes, are underexplored. In this paper, we aim to provide an overview of the molecular aspects of TGCTs, drawing a parallel between the findings in adult and pediatric groups.

Abstract: Cancer is a leading cause of death by disease in children and the second most prevalent of all causes in adults. Testicular germ cell tumors (TGCTs) make up $0.5 \%$ of pediatric malignancies, $14 \%$ of adolescent malignancies, and are the most common of malignancies in young adult men. Although the biology and clinical presentation of adult TGCTs share a significant overlap with those of the pediatric group, molecular evidence suggests that TGCTs in young children likely represent a distinct group compared to older adolescents and adults. The rarity of this cancer among pediatric ages is consistent with our current understanding, and few studies have analyzed and compared the molecular basis in childhood and adult cancers. Here, we review the major similarities and differences in cancer genetics, cytogenetics, epigenetics, and chemotherapy resistance between pediatric and adult TGCTs. Understanding the biological and molecular processes underlying TGCTs may help improve patient outcomes, and fuel further investigation and clinical research in childhood and adult TGCTs.

Keywords: testicular cancer; germ cell tumors; genomics; epigenomics; pediatric and adult

\section{Introduction}

Testicular germ cell tumors (TGCTs) are a distinctive set of diseases in oncology practice due to their curability or the mixture of histologies that appears to reflect embryogenesis. TGCTs are the most common solid tumor in young adults, representing $0.4 \%$ of new cases from all sites [1]. In early ages, germ cell tumors represent $3.5 \%$ of childhood cancers, occurring in a bimodal distribution with one peak in the first four years of life and a second in adolescence [2,3], and TGCTs represents about $20 \%$ of all cases [4]. The incidence rate of testicular germ cell tumors starts to increase in the late teens (10 years old) and reaches its peak in the young adult age group [5-7].

TGCTs are classified according to genotype, phenotype, origin cell, and germ cell neoplasia in situ (GCNIS) relationship into three groups. Type I is rare in postpubertal testis and presents as a yolk sac tumor in children less than 6 years old and no precursor 
cell is identified. Type II is common in postpubertal men in the third and fourth decades of life, with GCNIS as a precursor, which leads to several histologies (see below). Type III usually affects men older than 50 years, and the spermatocitic tumor is a phenotype that is not related to GCNIS. In the current study, we focus on TGCT Types I and II [8].

TGCTs are organized into two main histological groups, known as seminoma (SE) and non-seminoma germ cell tumors (NSGCTs). Seminoma GCTs are made up of undifferentiated germ cells that can histologically resemble sperm and young oogonia, or even germ cells from developmental strains. NSGCTs are subdivided into several histologies, such as embryonal carcinoma, yolk sac tumors (YSTs), teratoma, choriocarcinoma, and mixed NSGCT, in which different histologies are present in different proportions. In contrast to embryonal carcinoma, which histologically resembles the blastocyst, YST has a complex endodermal morphology with embryonic and extraembryonic endodermal components. Mature teratomas are benign tumors, and are the most differentiated, although they may harbor unique neural differentiation as immature teratomas. Finally, choriocarcinoma has trophoblastic differentiation and characteristically features a high level of human chorionic gonadotropin (hCG) in the bloodstream [9].

The clinical presentation of TGCTs usually involves painless swelling of one testis, and is sometimes perceived at a late stage in adults by the partners, and by parents in children. However, it may present with an enlarged tumor or even a palpable abdominal mass when the diagnosis is made at a late stage [10].

Cisplatin is the most important drug used to treat TGCTs and, in recent decades, has changed the natural history of the disease $[11,12]$. To date, no other drug has outperformed the results of platinum-based combinations; this includes carboplatin, which, in the adult population, has had inferior results [13,14]. Different combinations and doses have been used in protocols for adults and children, often to reduce the acute and late toxic effects, without compromising the outcomes in the latter group [15].

TGCTs have different survival rates according to the age group, with adolescents having a lower rate of event-free survival in a 3 year period (59.9\%) compared to children $(87.2 \%)$ or adults $(80.0 \%)[3,16]$. Twenty to forty percent of patients with metastatic testicular germ cell tumors relapse after first-line chemotherapy [11,12]. Furthermore, approximately $50 \%$ of these patients can still be cured, and histology, primary tumor location, response to first-line therapy, tumor marker concentrations, and location of metastases (liver, brain, and bone) have been proven to be important prognostic indicator factors in testicular germ cell tumors, in addition to the dose of chemotherapy [17].

Different cytogenetic abnormalities are described when comparing the age of presentation [8]. TGCTs are tumors with a low mutational load, but in their postpubertal presentation, mutations in genes such as KRAS, KIT, and TP53 play a role, in addition to the changes in the number of copies of the KRAS gene $[8,18]$. Epigenetics has been the focus of attention in TGCTs. SE and NSGCTs have different methylation patterns, and interest in the role of miRNA is growing, particularly miR-371a-3p and miR-375 as potential biomarkers [18-20].

Although most studies have evaluated the biology and molecular changes in adults, and there is a lack of information in children, the molecular mechanisms involved in the development of adult TGCTs are beginning to be defined, and share significant differences and similarities with pediatric GCTs. The search for cytogenetic alterations, epigenetics, and events related to resistance has been explored in TGCTs. In this study, we review the molecular aspects of TGCTs, drawing a parallel between the findings in the adult and pediatric groups.

\section{Etiopathogenesis of TGCT in Child and Adults}

Curiously, the pathogenesis of TGCT begins in utero during embryogenesis, when embryonic stem cells give rise to the primordial germ cells in the genital crest present in the midline of the embryo [21,22]. Pathogenesis differs in some aspects of differentiation, histogenesis, and genomic instability between adults and children. Primordial germ cells 
are the most implicated in studies on the tumorigenesis of germ cell tumors, and due to their totipotent nature, TGCTs have a wide range of possible histologies. In Type I TGCTs, prepubertal teratomas, as benign tumors, have limited developmental potential and may arise during the migration of primordial germ cells. However, the chromosomal loss of $1 \mathrm{p}$, 4 , and $6 q$, in addition to $1 q, 12,20 q$, and 22 , are implicated in the development of malignant YSTs, the histology most frequently found in testicular tumors in childhood $[9,23]$.

In Type II TGCTs, primordial germ cells and gonocytes may fail to be differentiated in spermatogonia, and the early onset of polyploidization coupled with OCT3/4 switch off failure and changes in genomic imprinting leads to germ cell neoplasia in situ (GCNIS) [24]. The GCNIS pathway is the origin of seminomatous and non-seminomatous TGCTs in adolescents and adults. This pre-invasive precursor of malignant tumors is histologically observed adjacent to normal tissue and is composed of undifferentiated germ cells that proliferate within a seminiferous tubule driven by the testis-specific Y-encoded protein (TSPY) $[25,26]$. The expression of the KIT ligand by Sertoli cells on the tubules completes the necessary milieu to promote germ cell tumorigenesis [27].

GCNIS commonly progresses to seminomas, and GCNIS and seminomas are able to reprogram the pluripotent embryonal carcinoma, the malignant counterpart of embryonal stem cell [28]. Differentiation steps lead to the emergence of other histologies from embryonal carcinoma, such as postpubertal teratoma, YST, and choriocarcinoma [29,30].

Type III TGCTs are represented by spermatocytic tumors and are more common in patients older than 50 years of age. They arise from differentiated spermatogonia, and the most important event in the oncogenesis appears to be the tumor-specific gain of chromosome 9 and, less frequently, mutations in HRAS and FGFR3 [8,23,31]. Figure 1 shows the etiopathogenesis of the three types of TGCTs.

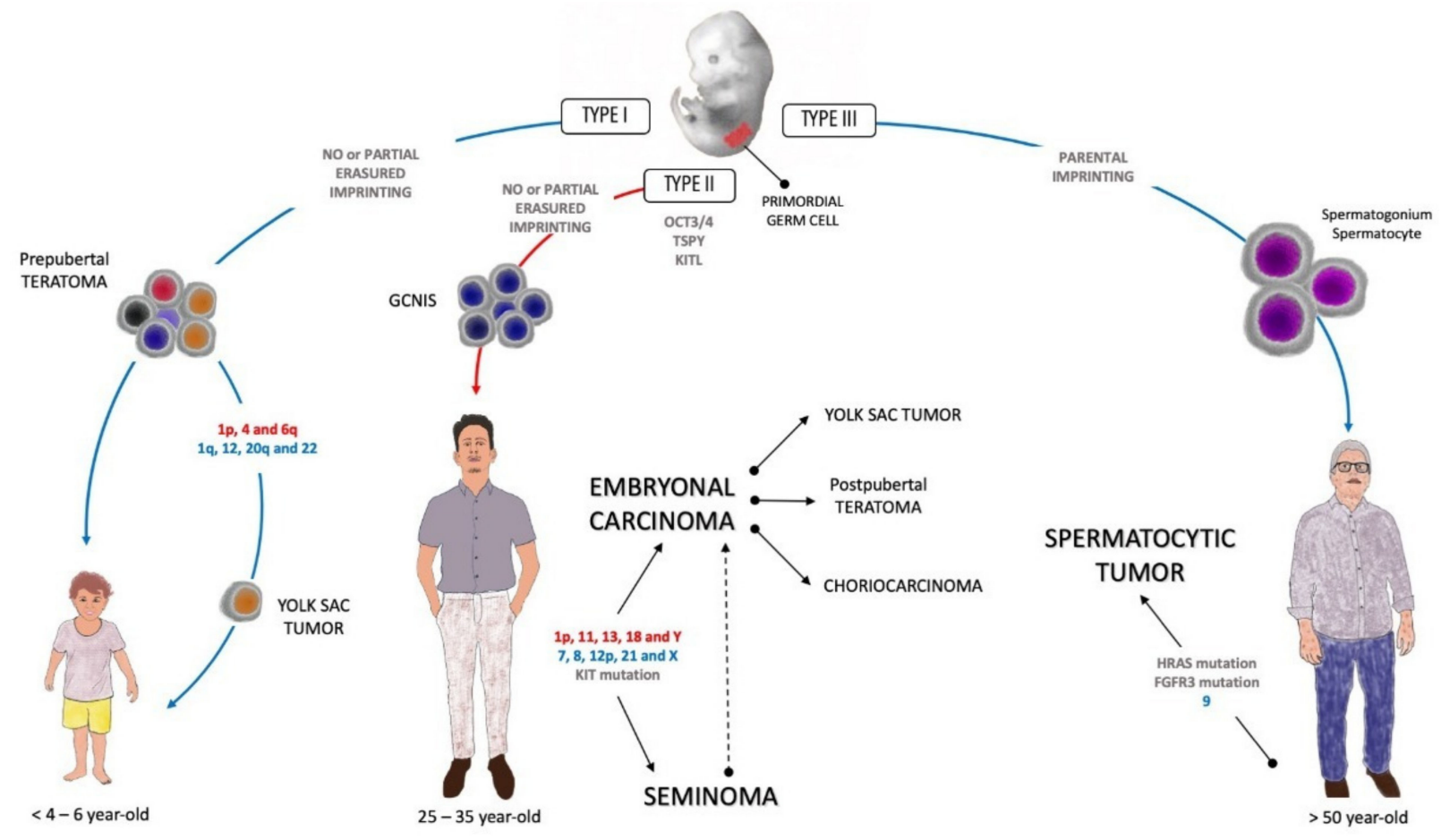

Figure 1. Etiopathogenesis of testicular germ cell tumors (TGCTs). The red letters mean chromosomic loss, and the blue letters chromosomic gain. The blue arrows represent the non-GCNIS pathway and the red arrow represents the GCNIS pathway. GCNIS: germ cell neoplasia in situ; KITL: KIT ligand; TSPY: testis-specific Y-encoded protein. 


\section{Molecular Biology}

Because TGCTs are a heterogeneous tumor, it is a challenge to study their genetic basis. However, in recent years, efforts have been made to understand the underlying molecular biology (Table 1) to further improve patient outcomes, particularly for those with chemoresistance and poor risk of disease.

\subsection{Genetics and Cytogenetics Alterations}

Genetic composition of GCTs reflects the embryonic characteristics of the primordial germ cells (PGCs) that give rise to this type of tumor. Although the molecular mechanisms involved in the development of adult TGCTs are beginning to be defined and share significant overlap with pediatric GCTs, little is known about the molecular biology of both, and it is believed that there are important differences that may represent different diseases [9].

TGCTs in adults are characteristically aneuploid, represented by hypertriploids in seminomas and hypotriploids in non-seminomas [32,33]. The most commonly observed change in all histological subtypes of adult TGCTs occurs in the short arm of chromosome 12 (isochromosome 12p), which is the trademark of TGCTs and an important biomarker [8,34,35]. Amplification in the number of copies of the KRAS gene reflects frequent alteration of the location of the gene on chromosome 12 and has been described as mutually exclusive with the KRAS mutation [36,37].

Other recurring gains at the arm level target chromosomes 7, 8, 21, 22, and X [38,39]. In contrast, in pediatric GCTs (Types I and II), the gain of the short arm of chromosome 12 (i12p) is less frequent, and the most common, but still inconsistent, changes include gains in $1 \mathrm{q}, 3,11 \mathrm{q}, 20 \mathrm{q}$, and 22 [9,40-43].

The occurrence of loss of heterozygosity (LOH) has been evaluated in TGCTs. In 2010, Vladusic et al. investigated the $\mathrm{LOH}$ in suppressor genes, including CDH1, APC, TP53, and $n m 23-H 1$ in TGCT patients (range, 17-60 years). An allelic loss of TP53 at exon 4 was detected in non-seminomas and $\mathrm{LOH}$ of TP53 at intron 6, APC, and CDH1 was detected in seminomas and non-seminomas. No changes were observed in the $n m 23-H 1$ gene [44]. In the subsequent studies, the same researcher group showed that $\mathrm{LOH}$ of the CDKN2A was found in two (6\%) non-seminomas cases with a yolk sac tumor component, and $\mathrm{LOH}$ of the RB1 was also found in two (6\%) non-seminomas with an embryonal carcinoma component [45]. In addition, patterns of $\mathrm{LOH}$ were analyzed in TGCT patients (range, 20-52 years) with seminoma components in mixed tumors, pure seminomas, and coexisting GCNIS lesions. $\mathrm{LOH}$ in seminoma components in mixed tumors (32\%) was more frequent compared to pure seminomas $(19 \%)$, and the frequencies of $\mathrm{LOH}$ at chromosomes $6 p$ and $10 q$ were significantly more frequent in seminoma components in mixed tumors than in pure seminomas [46]. Identification of specific genetic changes, especially events that occurs in adult and pediatric with TGCTs, need to be explored further.

Although TGCTs in adults have a low frequency of recurrent somatic point mutations, the mutational status of pediatric TGCTs is still poorly understood. Unlike most solid tumors, mutations in the TP53 gene have been rarely described in TGCTs and, when present, they have been associated with a cisplatin-resistant disease, especially in patients with non-seminomatous mediastinal GCTs [47-50]. Amplifications of the MDM2 gene have also been associated with mutations in TP53, suggesting that mutually exclusive changes in TP53/MDM2 were related to cisplatin-resistant tumors and, consequently, with unfavorable clinical outcomes [51,52]. In contrast, the integrity of the TP53 gene is considered to be the main reason why GCTs demonstrate high sensitivity to platinum-based chemotherapy [53]. Moreover, other studies have evaluated the presence of mutations in TGCTs, and alterations in FGFR3, AKT1, and PIK3CA genes have been associated with cisplatin-resistant GCTs [54].

KIT and KRAS mutations are consistently described, suggesting that these are the main conductive mutations of GCTs $[18,50,55]$. The KIT signaling pathway is essential for the normal development and survival of PGCs and spermatogenesis. Mutations in this gene have been reported mainly in seminomas and less frequently in NSGCTs $[39,52,56]$. In 
addition, Mata et al. showed that KIT mutations in GCTs are associated with RAS/MAPK pathway driver alterations. This was a retrospective cohort study, in which 568 GCTs patients were analyzed, and $8.1 \%(46 / 568)$ had somatic KIT mutations, and the median age at initial pathologic diagnosis of patients with KIT-mutant GCTs was 33.4 years (range, 7.2-58.9 years). Among the 46 patients with somatic KIT mutations, 23 were men with testicular GCTs, of which six (three seminomas and three NSGCTs) were significantly enriched for oncogenic $R A S / M A P K$ pathway mutations [57].

The genes of the RAS family (HRAS, KRAS, and NRAS) are fundamental for the migration, survival, and progression of the cell cycle, and for activating several downstream routes, including the $R A F / M E K / E R K$ and $P I 3 K$ routes [58,59]. According to the catalogue of somatic mutations in cancer (COSMIC) database, the frequency of KRAS and NRAS mutations in TGCT is 5\% and 3\%, respectively. Mutations in the genes of the RAS family are more common in seminomas than non-seminomas [36,60,61]. The mutational status of the $B R A F$ and $K R A S$ was analyzed in 70 pediatric GCT patients (range, 0.5-18 years), of which 17 were testicular; however, no mutations were found [62].

Our group determined the frequency and clinical impact of microsatellite instability status and BRAF mutations in 150 TGCT cases, in which the mean age of diagnosis was 30 years (range, 1-63 years). In accordance with the majority of the studies, any case or cell line harboring a $B R A F$ mutation was identified, and the microsatellite instability [63]. We also evaluated the presence of the hotspot telomerase reverse transcriptase (TERT) gene promoter mutations in more than 130 TGCT cases [64]. We showed for the first time the presence of the TERT promoter mutation in four patients $(\sim 3 \%)$, which is a rare event of TGCTs. Further cohort studies are needed to elucidate these findings and to improve clinical management, leading to better therapeutic alternatives.

Overall, TGCTs in adults and children have a low frequency of somatic mutations and genetic abnormalities is rare. However, adults and pediatric patients showed isochromosome 12p and gain at the chromosome 22 and absence of BRAF mutation. Gains in 1q, $3,11 q$, and $20 \mathrm{q}$ are frequent in TGCT pediatric patients, whereas gains of $7,8,21$, and $X$ are frequent in adults. In addition, KIT, RAS family, FGFR3, AKT1, PIK3CA, TP53, and TERT mutations have also been demonstrated in adults. Further studies with whole exome sequencing are necessary to identify gene mutations associated with pediatric and adult patients with TGCTs.

\subsection{DNA Methylation}

The epigenetic mechanism in cancer development is well established, with a major focus on DNA methylation. However, compared to other cancers, TGCTs are stated to be hypomethylated, which makes it difficult to uncover methylation-based biomarkers $[65,66]$. It has been reported that seminomas contain reduced levels of DNA methylation compared to NSGCTs $[65,66]$. Seminomas show quite low levels of DNA methylation, similar to PGCs or GCNIS, whereas non-seminomas show different extents of DNA methylation. The DNA methylation of NSGCTs has been associated with the degree of differentiation, such as hypermethylation in teratomas, YSTs, and choriocarcinomas, whereas embryonic cell carcinomas show an intermediate pattern [66-68]. Smiraglia et al. evaluated the epigenetic differences between seminomas and non-seminomas by restriction landmark genomic scanning and found a level of CpG island methylation in NSGCTs (1.11\%) similar to that of other solid tumors, whereas seminomas showed almost no CpG island methylation $(0.08 \%)$ [66].

To elucidate a set of potential biomarkers in TGCTs, our group evaluated the frequency of methylation of a gene panel (VGF, MGMT, ADAMTS1, CALCA, HOXA9, CDKN2B, CDO1, and $N A N O G$ ) in primary TGCT samples, which included seminomas and NSGCTs. We observed a high frequency of MGMT and CALCA methylation in NSGCTs and demonstrated for the first time that CALCA methylation is associated with non-seminoma tumors, refractory disease, and poor clinical outcome in TGCT patients (range, 26-32 years) [69]. Similar to our results were those obtained by Sanjay et al., in which the characteristic 
promoter hypermethylation signatures in male germ cell tumors were determined via analysis of CpG islands of 21 gene promoters by methylation-specific PCR in seminoma and non-seminoma GCTs. NSGCTs showed $60 \%$ of methylation in one or more gene promoters, including MGMT, RASSF1A, BRCA1, and a transcriptional repressor gene HIC1. In contrast, seminomatous tumors showed a near-absence of methylation [70]. Promoter hypermethylation of RASSF1A and HIC1 was associated with tumors resistant to cisplatin-based regimens in a cohort of GCTs, whereas MGMT and RARB were sensitive [71].

Some of the epigenetic markers have been explored as diagnostics of TGCTs. The methylation status of XIST was investigated, and unmethylated XIST sequences were detected in most tissues (30/31) (seminoma and non-seminoma) and plasma (16/25) samples from patients with TGCTs, contrasting with peripheral blood lymphocytes from non-germ cell tumors of individuals (no detection). The Nodal co-receptor Cripto is another useful serological marker proposed for TGCT diagnosis. Hypomethylation of the CRIPTO promoter was found in undifferentiated fetal germ cells, embryonal carcinomas, and seminomas, whereas hypermethylation was associated in differentiated fetal germ cells and the differentiated types of NSGCTs [72]. These results suggest the methylation status of XIST and CRIPTO could be a tumor marker for detection and monitoring of TGCTs, however, confirmation from a larger series is necessary [73].

Methylation studies involving adults are significantly more common than those of children. In 2003, Kato et al. evaluated promoter methylation in yolk sac tumors from infants and the results showed that methylation of RUNX3 was detected in $80 \%$ of infantile YSTs examined, and no adult GCTs showed RUNX3 methylation [74]. In 2006, the same research group showed that the APC promoter was methylated in $7(70 \%)$ of 10 infantile YSTs. Taken together, these results suggest that RUNX3 and APC are the tumor suppressors involved in the pathogenesis of testicular YSTs in infants (Kato et al., 2006) [75].

The heritability of the global genomic methylation phenotype in families and the association between global (LINE-1) methylation levels and testicular cancer was examined [76]. The heritability of LINE-1 methylation may be gender-specific and there was a marginally significant inverse association between LINE-1 hypomethylation levels and increased TGCT risk [76].

The differences in methylation between the histologic subtypes of pediatric GCTs were analyzed using in an epigenome-wide study. The differentially methylated regions (DMRs) were identified in a set of 154 pediatric tumors, including germinomas/seminomas/dysgerminomas, teratomas, YSTs, and a mixed histologic subtype from gonadal, extragonadal, and intracranial locations. A total of 8481 DMRs were identified (family-wise error ratesFWER $<0.05$ ) and distinct differences in gene-specific methylation were found between the histologic subtypes of GCT, particularly between germinoma/seminoma/dysgerminoma and YST. Pathway analysis on the top 10\% of genes with differential methylation suggested angiogenesis and immune cell-related pathways, which displayed decreased methylation in germinomas/seminomas/dysgerminomas relative to YST. Therefore, the genes that are differentially methylated may provide insights into GCT etiology [77].

In summary, most works on altered DNA methylation patterns in TGCTs have been performed in adults showing methylation in the following genes: VGF, MGMT, ADAMTS1, CALCA, HOXA9, CDKN2B, CDO1, NANOG, RASSF1A, BRCA1, HIC1, RARB, XIST, and CRIPTO. Few studies have been realized in TGCT pediatric patients, and only RUNX3 and $A P C$ methylation has been described. There is a wide information gap between TGCTs in adult and children, and only one gene (LINE-1) was reported to be hypomethylated in both age groups. Overall, the elucidation of epigenetic alterations in TGCTs including the study of mutations could improve the usefulness of methylation-based biomarkers.

\section{3. miRNAs as Tumor Biomarkers}

Recent studies have suggested an involvement of microRNAs (miRNAs) as tumor biomarkers and therapeutic targets. MiRNAs comprise a group of small (approximately 22 nucleotides) non-coding RNAs that regulate the expression of protein-coding genes by 
binding to their target messenger RNAs (mRNAs), thus resulting in translational repression or mRNA degradation $[78,79]$. Several studies have revealed the role of miRNAs in a variety of biological processes, including development, differentiation, viral infections, and cancer [80]. There are more than 1000 mature miRNAs [81] and some of them have been associated with malignant-GCTs as a new generation of biomarkers [19].

In 2006, Voorhoeve et al. performed a screen for miRNAs that cooperate with oncogenes in cellular transformation, and found $\mathrm{miR}-372$ and miR-373 were particularly abundant in GCT tissue and cell lines [82]. In agreement with these results, Palmer et al. determined the global miRNA profiles in pediatric GCTs arising at both gonadal and extragonadal sites, and compared the changes observed with those reported for adult gonadal malignant GCTs [83]. The most significant differentially expressed miRNAs in malignant GCTs were all from the miR-371 373 and miR-302 clusters, which were over-expressed regardless of histological subtype (yolk sac tumor/seminoma/embryonal carcinoma), site (gonadal/extragonadal), or patient age (pediatric/adult). Subsequently, the potential of miR-371 373 and miR-302/367 as biomarkers of malignant GCTs was reported [84]. In a multicentric study, serum samples of 616 patients with TGCTs (range, 16-69 years) and 258 male controls were examined for serum levels of miRNA-371a-3p. The results showed that the measurement of serum miR-371a-3p levels provides both a sensitivity and a specificity greater than $90 \%$ and an area under the curve (AUC) of 0.96 [20]. These data support the use of miRNAs as tumor biomarkers.

The use of circulating miR-371a-3p was analyzed as a marker for malignant germ cell tumor management in TGCT patients (range, 26-40 years) prior to orchiectomy [85]. Performance characteristics of serum miR-371a-3p were compared with predictable markers, including $\alpha$-fetoprotein, $\beta$-human chorionic gonadotropin, and lactate dehydrogenase. The miR-371a-3p test showed a specificity of $100 \%$, sensitivity of $93 \%$, and AUC of 0.978 [85]. These results confirm the previously published studies and suggest the effectiveness of a positive miR-371a-3p test post-chemotherapy.

Micro-RNA expression was also associated with cisplatin-resistant germ cell tumor cell lines. There is an association of the upregulation of miR-512-3p/-515/-517/-518/-525 and down-regulation of miR-99a/-100/-145 with a cisplatin-resistant phenotype in human germ cell tumors [86]. However, it will be interesting to evaluate tumor samples of patients with germ cell tumors with both cisplatin-sensitivity and resistance to analyze whether all of these miRNAs are also found in vivo.

Similarly, studies have paid particular attention to miR-371 373 and miR-302 clusters across age groups (pediatric and adult patients). Further experimental support is required to confirm the high sensitivity and specificity of miRNAs as biomarkers of TGCTs and, with this confirmation, the miRNAs will be considered clinical biomarkers to overcome the uncertainty of equivocal scenarios, for which the rate of uncertainty is concerning. Finally, miRNAs may improve the quality of the care of patients, contributing to personalized and precise medicine. 
Table 1. Epigenetic-based biomarkers in testicular germ cell tumors in adult and pediatric patients.

\begin{tabular}{|c|c|c|c|}
\hline \multicolumn{2}{|r|}{ Adult } & \multicolumn{2}{|r|}{ Pediatric } \\
\hline Biomarker & Major Findings & Biomarker & Major Findings \\
\hline \multicolumn{4}{|l|}{ DNA Methylation } \\
\hline $\begin{array}{c}\text { VGF, MGMT, ADAMTS1,CALCA, } \\
\text { HOXA9, } \\
\text { CDKN2B, CDO1, and NANOG }\end{array}$ & $\begin{array}{c}\text { Hypermethylation of } M G M T \text { and } C A L C A \\
\text { promoters associateswith non-seminoma and } \\
\text { poor prognosis CALCA associates } \\
\text { with refractory disease. [69] }\end{array}$ & RUNX3 & $\begin{array}{l}\text { RUNX3 promoter } \\
\text { hypermethylation was detected in } \\
\text { YST in infants }(80 \%) \text {. [74] }\end{array}$ \\
\hline $\begin{array}{c}\text { MGMT, RASSF1A, BRCA1, and a } \\
\text { transcriptional repressor gene } \\
\text { HIC1 }\end{array}$ & $\begin{array}{c}\text { Non-seminoma showed methylation in } \\
\text { MGMT, RASSF1A, and BRCA1 and HIC1. } \\
\text { Seminoma showed a near-absence of } \\
\text { methylation. [70] }\end{array}$ & $A P C$ & $\begin{array}{c}\text { APC promoter hypermethylation } \\
\text { was detected in YST in infants } \\
(70 \%) .[75]\end{array}$ \\
\hline $\begin{array}{c}\text { RASSF1A, HIC1, MGMT, and } \\
\text { RARB }\end{array}$ & $\begin{array}{c}\text { Hypermethylation of } R A S S F 1 A \text { and } H I C 1 \text { was } \\
\text { associated with tumors resistant to } \\
\text { cisplatin-based regimens, whereas } M G M T \text { and } \\
\text { RARB were sensitive. [71] }\end{array}$ & $\begin{array}{l}\text { Epigenome-wide } \\
\text { study }\end{array}$ & $\begin{array}{l}\text { DMRs were identified in a set of } \\
154 \text { pediatric tumors from } \\
\text { gonadal, extragonadal and } \\
\text { intracranial locations. [77] }\end{array}$ \\
\hline XIST & $\begin{array}{l}\text { Unmethylated DNA XIST fragments in } \\
\text { seminoma and non-seminoma. [73] }\end{array}$ & & \\
\hline CRIPTO & $\begin{array}{l}\text { Hypomethylation in undifferentiated fetal } \\
\text { germ cells, embryonal carcinoma and } \\
\text { seminomas. Hypermethylation in } \\
\text { differentiated fetal germ cells and the } \\
\text { differentiated types of non-seminomas. [72] }\end{array}$ & & \\
\hline LINE-1 & $\begin{array}{r}\text { Strong correlation in LINE-1 methylation } \\
\text { hypomethylation was associ }\end{array}$ & $\begin{array}{l}\text { vels among affected } \mathrm{f} \\
\text { ed with the risk of tes }\end{array}$ & $\begin{array}{l}\text { er-affected son pairs. LINE-1 } \\
\text { ular cancer. [76] }\end{array}$ \\
\hline \multicolumn{4}{|l|}{ Genetic abnormalities } \\
\hline Isochromosome $12 \mathrm{p}$ & $\begin{array}{l}\text { The most commonly observed change in all } \\
\text { histological subtypes of TGCTs. }[8,34,35]\end{array}$ & Isochromosome $12 p$ & $\begin{array}{l}\text { Less frequent in types I and II. } \\
\text { [40-42]. }\end{array}$ \\
\hline Chr $7,8,21,22$, and $X$ & Gains at the arm level target. [38,39] & $\begin{array}{l}\text { Chr } 1,3,11,20 \text {, and } \\
22\end{array}$ & $\begin{array}{c}\text { Gains in } 1 q, 3,11 q, 20 q \text {, and } 22 \text { are } \\
\text { common, but still inconsistent. } \\
{[9,43]}\end{array}$ \\
\hline $\begin{array}{c}\text { RAS family }(H R A S, K R A S, \text { and } \\
\text { NRAS) }\end{array}$ & $\begin{array}{l}\text { More common in seminoma when compared } \\
\text { to non-seminoma }[36,60,61] \text {. }\end{array}$ & & \\
\hline $\begin{array}{c}\text { TP53 } \\
\text { FGFR3, AKT1, PIK3CA } \\
\text { TERT } \\
\text { KIT and KRAS } \\
\text { BRAF }\end{array}$ & $\begin{array}{l}\text { Rarely described in GCTs but, when present, } \\
\text { they were associated with a cisplatin-resistant } \\
\text { disease, especially in patients with } \\
\text { non-seminoma mediastinal [47-50]. } \\
\text { Associated with cisplatin-resistant GCTs [54]. } \\
\text { TERT promoter mutation is rare [64]. } \\
\text { KIT mutations in GCTs are associated } \\
B R A F \text { mutatic }\end{array}$ & $\begin{array}{l}\text { ith } R A S / M A P K \text { path } \\
\text { was absent }[62,63,87 \text {, }\end{array}$ & y driver alterations [57]. \\
\hline \multicolumn{4}{|l|}{ microRNA } \\
\hline miR-372 and miR-373 & $\begin{array}{l}\text { miR-372 and miR-373 were particularly } \\
\text { abundant in GCT tissue and cell lines. [82] }\end{array}$ & $\begin{array}{l}\text { miR-371 373 and } \\
\text { miR-302 clusters }\end{array}$ & $\begin{array}{l}\text { miR-371 373 and miR-302 } \\
\text { clusters were overexpressed } \\
\text { regardless of histological subtype, } \\
\text { site (gonadal/extragonadal), or } \\
\text { patient age (pediatric/adult) [83]. }\end{array}$ \\
\hline miR-371 373 and miR-302/367 & $\begin{array}{c}\text { miR-371 373 and miR-302/367 as biomarkers } \\
\text { of malignant GCTs were reported [84]. } \\
\text { Serum miR-371a-3p levels provide both a } \\
\text { sensitivity and a specificity greater than } 90 \% \\
\text { and an area under the curve (AUC) of } 0.96 \text { [20]. } \\
\text { The miR-371a-3p test showed a specificity of } \\
\text { 100\%, sensitivity of } 93 \% \text {, and AUC of } 0.978 \\
\text { [85]. }\end{array}$ & & \\
\hline
\end{tabular}

\subsection{Molecular Implications Responsible for Chemotherapy Sensitivity and Resistance in TGCTs}

Due to the efficacy of cisplatin treatments for TGCTs and the high five-year survival rate, TGCTs are considered curable neoplasms [89]. However, resistance to chemotherapeutic treatment still appears in around $20 \%$ of patients with metastatic disease [90].

Studies have focused on the molecular events responsible for the cisplatin (CDDP) resistance mechanisms, in addition to the high chemotherapy sensitivity of TGCTs, to develop a more effective treatment for patients with metastatic cancers. Based on this statement, we pose the following question: Why are some TGCT patients so sensitive to CDDP and resistant to others?

The resistance of TGCT to chemotherapy has been related to different molecular mechanisms, including mutations, karyotype abnormalities, and epigenetic aberrations. 
Cisplatin acts via covalent binding to the DNA molecule, which is recognized by proteins participating in the process of DNA repair, leading to cell cycle arrest and apoptosis [91].

The sensitivity to CDDP might be explained by the inherent properties of the embryonal stem cells (ESCs) [92], which react to DNA damage through the elimination of damaged cells by apoptosis $[93,94]$. Therefore, the loss of the embryonic properties might underlie the development of treatment resistance.

Studies have shown a model of cisplatin-sensitive GCT. When the cisplatin-sensitive germ cell tumor cells suffer DNA damage (e.g., cisplatin), the DNA damage response system is activated, in which TP53 is activated and a mediated response occurs via induction of PUMA and NOXA, leading to apoptosis. The apoptosis response is enhanced by the presence of transcription factor OCT4, and high levels of OCT4 are associated with low expression of $P 21$ and failure to activate a G1 arrest [91]. In contrast to other solid tumors, GCT is rarely characterized by TP53 mutation. One study showed that in relapsed GCTs, TP53 mutations were detected in about $14 \%$ of tumors ( 4 of 28 tumors), for which three were mature teratomas and the other was a secondary non-germ-cell malignancy derived from a teratoma [48]. Kersemaekers et al. investigated the role of TP53 and MDM2 in the treatment response of patients (range, 17-56 years) with germ cell tumors. Mutation analysis revealed only one silent TP53 mutation in one of the responding patients. All embryonal carcinomas were homogeneously positive for $M D M 2$, whereas the other histologic components were heterogeneous. Only one patient $(1 / 12)$ with embryonal carcinomas showed MDM2 amplification. Although the presence of wild-type TP53 was detected in TGCTs, there is no correlation between the high level of TP53 and treatment sensitivity, and a TP53 inactivation is a rare event in the development of cisplatin resistance [51].

Studies have suggested that mutations in TP53 and overexpression of MDM2 may happen in proportion to cisplatin refractory TGCTs; however, the extent of these mutations is not clear [50,52]. Therefore, the role of TP53 mutations in cisplatin resistance of TGCTs has been controversial and more studies are required.

Defective mismatch repair (MMR), microsatellite instability, and BRAF mutations have been associated with relapse and treatment failure in TGCT patients (range, 18-55 years), who show a decrease in the MMR gene expression (MLH1, MLH2, or MSH6) [95].

Feldman et al. attempted to validate the frequency of $B R A F$ mutations among GCT patients. Adolescent and adult patients (range, 14-60 years) with GCT who received cisplatin-based chemotherapy were classified as cisplatin-sensitive and cisplatin-resistant. Nineteen mutations were detected in GCTs patients, but no $B R A F$ mutations were identified. Somatic mutations within KRAS, AKT1, PIK3CA, and HRAS were exclusive to cisplatin-resistant patients [54]. Genomic evolution and chemoresistance was analyzed by Taylor-Weiner et al. using whole-exome and transcriptome sequencing of precursor, primary (testicular and mediastinal), and chemoresistant metastatic human GCTs ( $\mathrm{n}=49$ patients; range, 17-57 years) [50]. Mutational significance analysis showed KRAS as the most significant altered gene and primary TGCTs were uniformly wild type for TP53. Moreover, TGCTs with chemotherapy resistance showed an additional reciprocal loss of heterozygosity, which was associated with loss of NANOG and POU5F1 markers $[96,97]$ in chemoresistant teratomas or transformed carcinomas. These results suggest that different genomic features underlying the origins of GCTs are related with the chemosensitivity phenotype [50].

Accumulating evidence suggests that cisplatin resistance is associated with an increase in DNA methylation. The promoter hypermethylation of RASSF1A and HIC1 genes have been related to resistance of GCT, whereas the transcriptional inactivation of MGMT confers sensitivity to cisplatin [71].

The mechanisms of cisplatin hypersensitivity and resistance in embryonal carcinoma were explored in human testicular cancer-derived EC cell lines. The data shows that repression of $H 3 \mathrm{~K} 27$ methylation is a mechanism of cisplatin acquired resistance in TGCTs and that restoration of $P R C 2$ function is a potential alternative to overcome treatment failure [98]. 
Cisplatin resistance is most likely multifactorial and is a challenge in the clinical approach to TGCT patients, especially in pediatric patients for whom there is a lack of research. There is a scarcity of large molecular analysis focusing on cisplatin resistance because targeting a single marker is not sufficient to reverse the phenotype. A better understanding of cisplatin resistance could improve the testing of new drugs and targeted therapies with better clinical benefit.

\section{In Vitro and In Vivo Models}

In recent years, major technological advancements have led to a better understanding of the molecular mechanisms of TGCTs. However, this progress has had a slight impact on the cancer therapeutic approach, probably due to the limitation of experimental models to predict efficacy in clinical trials. In an effort to offset this limitation, the interest in the development of different TGCT models is increasing.

It remains a challenge for the clinic to investigate the molecular and genetic mechanisms involved in the development of cisplatin resistance in TGCTs, for which the frequency of recurrence is low and the availability of histological samples post-chemotherapy is scarce, because surgical resection of the tumor is the first line of treatment [99]. In general, cisplatin resistance in TGCTs is commonly studied in primary tumors of patients who may develop them at some point in the future, which is not ideal due to its naive relationship with chemotherapy [100].

Other strategies to investigate the mechanisms associated with the resistance acquired by tumor cells to cisplatin include the use of preclinical models, in vitro and in vivo, obtained from the cultivation and exposure of TGCT cell lines to incremental doses of the drug, for long periods of time [101], in addition to the use of animal models that reproduce the phenotypic properties of the human tumor [102]. Although in vitro cell culture systems have been used extensively for decades, they represent oversimplified models, which are characterized by the absence of heterogeneity and lack of microenvironment components [103]. Therefore, it is crucial to develop more accurate and clinically relevant mice models that genuinely represent TGCTs in adult and pediatric patients, according to their etiopathogenesis, histopathology, and metastatic progression, and the response of therapy. In this context, patient-derived xenograft (PDX) models have been used as an outstanding alternative [104,105]. PDX model development is generated via the transplant of primary tumor fragments or tumor-derived cancer cells from the patient into immunocompromised mice $[106,107]$, and has been established in different types of tumors. In TGCTs, PDX models have been developed with a focus on mouse models of resistant disease, which may be established by injecting the cisplatin-resistant clones of TGCT cell lines or by implanting cisplatin-resistant human tumors [102,108,109].

Different models of chemoresistant TGCT cell lines have already been developed and studied for genotypic and phenotypic changes [99]. NTERA-2 and NCCIT cisplatinresistant cell lines were injected into immunodeficient mice and disulfiram was used to examine chemosensitization of resistant cell lines. Disulfiram in combination with cisplatin showed synergy for NTERA-2 and NCCIT cisplatin-resistant cells and inhibited the growth of NTERA-2 (cisplatin-resistant) xenografts. High ALDH1A3 expression and increased $A L D H$ activity were detected in both refractory cell lines. In addition, the upregulation of the $A L D H$ isoform $A L D H 1 A 3$ was confirmed in 216 patient samples with all histological subtypes of testicular tumors. These results suggest $A L D H 1 A 3$ as a novel therapeutic treatment in TGCTs, and disulfiram represents a feasible treatment option for refractory TGCTs [109].

Our group developed an in vitro model of cisplatin resistance to identify new potential therapies for TGCT-resistant patients (data not published). We established a CDDPresistance model using the NTERA-2 cell line (NTERA-2R), which was treated for approximately eight months with incremental doses of CDDP. We then performed a phenotypical characterization and NTERA-2R exhibited a significant increase in cell proliferation capacity, augmented clonogenic survival, and higher migration ability, suggesting an aggressive 
phenotype. To elucidate the molecular changes associated with CDDP-resistance, we analyzed the expression of genes related to damage and repair mechanisms. Compared to the parental cell line, NTERA-2R showed several differentially expressed genes related to DNA repair and cell cycle regulation. These results support the idea that the main change in NTERA-2R is possibly an increased DNA repair capacity and specific changes in cell cycle control, which may trigger apoptosis evasion and allow cells to proliferate, even in the presence of CDDP adducts.

Changes in the cell cycle (increase in G1 and decrease in the S phase), increase in the number of acquired mutations (mainly in the ATRX gene), changes in the gene expression pattern, and chromosomal variation (gain of 12p, 1, 17, 20, and 21 loss of $X$ ) were also observed in the resistant NCCIT strain [100].

To investigate cisplatin-resistance genetic basis in TGCT, Piulats et al. implanted a collection of matched cisplatin-sensitive and -resistant non-seminoma tumors in nude mice and compared the genomic hybridization (CGH). Comparative CGH analyses showed a gain at the 9q32-q33.1 region, and the presence of this chromosomal rearrangement was correlated with poorer overall survival (OS) in metastatic germ cell tumors. Moreover, POLE3 and AKNA genes were deregulated in resistant tumors harboring the 9q32-q33.1 gain. Therefore, the cisplatin-refractory orthoxenografts of TGCTs are potent models to test the efficiency of drugs, and identify prognosis markers and gene alterations [102].

An immunohistochemical study investigated xenograft models and NSGCT samples with a focus on OCT4-negative cells with undifferentiated EC morphology and their association with chemotherapy resistance [108]. Subcutaneous xenograft tumors of the NSGCT cell lines H12.1 (cisplatin-sensitive) and 1411HP (cisplatin-resistant) were established in athymic nude mice. The cisplatin-sensitive cell line H12.1 leads to xenografts in which EC structures are mainly composed of OCT4-positive cells, whereas xenografts from the resistant cell line 1411HP exclusively comprise OCT4-negative EC areas, suggesting that the growth of NSGCTs in patients with cisplatin-refractory disease may be determined by OCT4-negative EC cells [108]. In addition to this data, a mouse TGCT model featuring germ cell-specific Kras activation and Pten inactivation was developed as a representative model of malignant TGCTs in men. The resulting mice developed malignant, metastatic TGCTs composed of teratomas and embryonal carcinomas, the latter of which exhibited stem cell characteristics, including expression of the pluripotency factor OCT4 [110].

The need for new therapeutic options for patients with natural or acquired resistance to cisplatin has led to the investigation of the activity of different compounds (kinase inhibitors directed at mTOR, EGFR, HER2, VEGFR, and IGF-1R), in sensitive (H12.1 and GCT72), and resistant (H12.1RA, H12.1D, 1411HP, and 1777NRpmet) cell lines of TGCT. Research has shown that these compounds have potential activity when used alone, but not when in combination with cisplatin [111].

Despite these recent advances in the use of mouse models to study TGCTs, such models must be developed for pediatric patients, and new molecular studies must be performed to provide powerful experimental tools to prioritize new therapeutic approaches for future clinical trials. Figure 2 summarizes the comparison of clinical and molecular differences between adult and pediatric patients with TGCTs as hallmarks of cancer. 


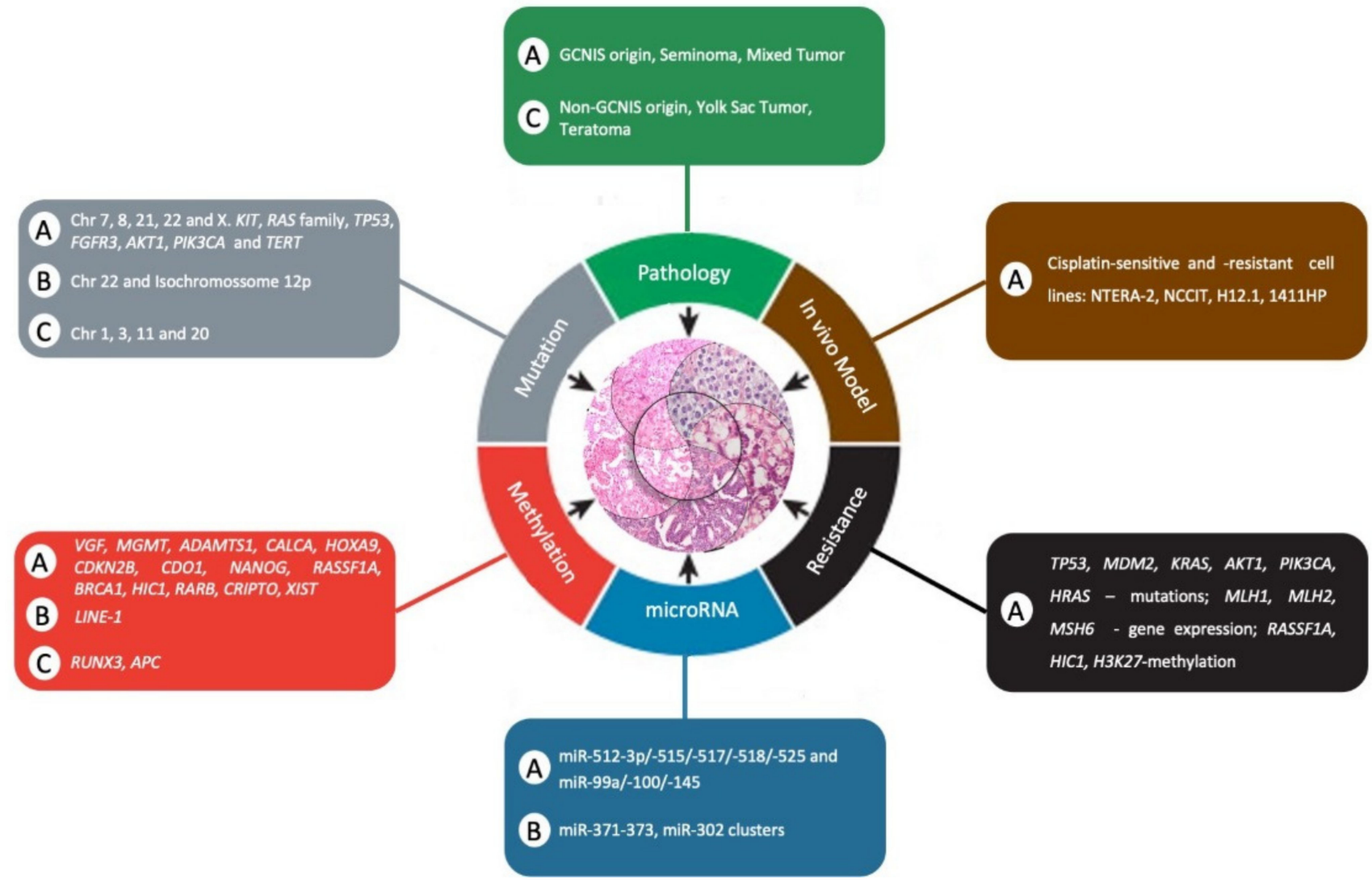

Figure 2. Comparison of clinical and molecular differences between adult and pediatric patients with TGCTs as a hallmark of cancer. The letter " $\mathrm{A}$ " represents adults, " $\mathrm{C}$ " represents child, and " $\mathrm{B}$ " represents both adult and child. Adapted from Hanahan and Weinberg [112].

\section{Conclusions}

Clinic presentation of TGCTs is highly similar between children and adults, although their identification and search for elucidation could be driven by different contexts. GCNIS is the main player in adult tumorigenesis, in contrast to child tumors, which arise from non-GCNIS pathways. The relative paucity of molecular studies in the pediatric group poses an inferential limitation to compare children and adults. However, advances in recent years provide a new perspective. Thus, miRNAs and methylation can be identified as similarities to highlight that are deserving of more attention.

Considering genetic abnormalities, TGCTs in adults and children have a low frequency of somatic mutations, and genetic abnormalities are rare. However, adults and pediatric patients showed isochromosome 12p and gain at chromosome 22, and absence of $B R A F$ mutation. Studies of adults have shown mutation in KIT, RAS family, FGFR3, AKT1, PIK3CA, TP53, and TERT. In contrast, there is a scarcity of research in TGCT pediatric fields.

Several epigenetic alterations have been demonstrated to impact TGCTs, and DNA methylation and microRNAs have been the most frequent targets of studies. Promoter methylation of VGF, MGMT, ADAMTS1, CALCA, HOXA9, CDKN2B, CDO1, NANOG, RASSF1A, BRCA1, HIC1, RARB, XIST, and CRIPTO have been reported in adults. Again, there is a lack of information in TGCT pediatric fields, and only RUNX3 and APC methylation have been described. Moreover, miRNAs, such as miR-371a-3p, have been shown to be expressed and detectable in the blood of adult and pediatric patients with viable GCTs. Thus, deep knowledge of the epigenetic mechanisms underlying the development of TGCTs may lead to new therapeutic approaches.

Knowledge of the biological and molecular insights underlying TGCTs may help improve patient outcomes and may fuel further translational and clinical research in childhood and adult TGCTs. Due to the rarity of TGCTs, it is hard to establish a large cohort 
of adults and, in particular, children, to compare the groups. However, collaborative efforts should be made to assemble these groups to enable a better etiopathogenic understanding involving children, adolescents, and adults. In addition, new therapeutic approaches might be achieved with the development of child in vivo models, thus leading to more effective and less toxic treatment protocols.

Author Contributions: Conceptualization: M.T.P. and F.M.C.; writing: M.T.P., F.M.C., E.R.M.C., and A.G.S.V.; revision and editing: L.F.L. All authors have read and agreed to the published version of the manuscript.

Funding: This work was supported by the Barretos Cancer Hospital internal research funds program (PAIP).

Acknowledgments: The authors would like to acknowledge the support of Rui Manuel Reis for his help and critical comments.

Conflicts of Interest: The authors declare no conflict of interest.

\section{References}

1. Sung, H.; Ferlay, J.; Siegel, R.L.; Laversanne, M.; Soerjomataram, I.; Jemal, A.; Bray, F. Global cancer statistics 2020: GLOBOCAN estimates of incidence and mortality worldwide for 36 cancers in 185 countries. CA Cancer J. Clin. 2021. [CrossRef] [PubMed]

2. Rescorla, F.J.; Ross, J.H.; Billmire, D.F.; Dicken, B.J.; Villaluna, D.; Davis, M.M.; Krailo, M.; Cullen, J.W.; Olson, T.A.; Egler, R.A.; et al. Surveillance after initial surgery for stage I pediatric and adolescent boys with malignant testicular germ cell tumors: Report from the Children's Oncology Group. J. Pediatric Surg. 2015, 50, 1000-1003. [CrossRef] [PubMed]

3. Lopes, L.F. Protocolo TCG-GALOP-2017: Tumores de Células Germinativas da Infância e Adolescência; Lemar: São Paulo, Brazil, 2018.

4. Murray, M.J.; Nicholson, J.C. Germ cell tumours in children and adolescents. Paediatr. Child Health 2010, 20, 109-116. [CrossRef]

5. Katanoda, K.; Shibata, A.; Matsuda, T.; Hori, M.; Nakata, K.; Narita, Y.; Ogawa, C.; Munakata, W.; Kawai, A.; Nishimoto, H. Childhood, adolescent and young adult cancer incidence in Japan in 2009-2011. Jpn. J. Clin. Oncol. 2017, 47, 762-771. [CrossRef] [PubMed]

6. Kusler, K.A.; Poynter, J.N. International testicular cancer incidence rates in children, adolescents and young adults. Cancer Epidemiol. 2018, 56, 106-111. [CrossRef]

7. Brenner, D.R.; Heer, E.; Ruan, Y.; Peters, C.E. The rising incidence of testicular cancer among young men in Canada, data from 1971-2015. Cancer Epidemiol. 2019, 58, 175-177. [CrossRef]

8. Oosterhuis, J.W.; Looijenga, L.H.J. Testicular germ-cell tumours in a broader perspective. Nat. Rev. Cancer 2005, 5, 210-222. [CrossRef]

9. Pierce, J.L.; Frazier, A.L.; Amatruda, J.F. Pediatric Germ Cell Tumors: A Developmental Perspective. Adv. Urol. 2018, 2018, 9059382. [CrossRef]

10. Shaikh, F.; Murray, M.J.; Amatruda, J.F.; Coleman, N.; Nicholson, J.C.; Hale, J.P.; Pashankar, F.; Stoneham, S.J.; Poynter, J.N.; Olson, T.A.; et al. Paediatric extracranial germ-cell tumours. Lancet. Oncol. 2016, 17, e149-e162. [CrossRef]

11. De Wit, R.; Stoter, G.; Sleijfer, D.T.; Neijt, J.P.; ten Bokkel Huinink, W.W.; de Prijck, L.; Collette, L.; Sylvester, R. Four cycles of BEP vs four cycles of VIP in patients with intermediate-prognosis metastatic testicular non-seminoma: A randomized study of the EORTC Genitourinary Tract Cancer Cooperative Group. European Organization for Research and Treatment of Cancer. Br. J. Cancer 1998, 78, 828-832. [CrossRef] [PubMed]

12. Culine, S.; Kramar, A.; Théodore, C.; Geoffrois, L.; Chevreau, C.; Biron, P.; Nguyen, B.B.; Héron, J.-F.; Kerbrat, P.; Caty, A.; et al. Randomized trial comparing bleomycin/etoposide/cisplatin with alternating cisplatin/cyclophosphamide/doxorubicin and vinblastine/bleomycin regimens of chemotherapy for patients with intermediate- and poor-risk metastatic nonseminomatous germ cell tumors: Genito-Urinary Group of the French Federation of Cancer Centers Trial T93MP. J. Clin. Oncol. Off. J. Am. Soc. Clin. Oncol. 2008, 26, 421-427. [CrossRef]

13. Bokemeyer, C.; Köhrmann, O.; Tischler, J.; Weissbach, L.; Räth, U.; Haupt, A.; Schöffski, P.; Harstrick, A.; Schmoll, H.J. A randomized trial of cisplatin, etoposide and bleomycin (PEB) versus carboplatin, etoposide and bleomycin (CEB) for patients with "good-risk" metastatic non-seminomatous germ cell tumors. Ann. Oncol. Off. J. Eur. Soc. Med Oncol. 1996, 7, $1015-1021$. [CrossRef] [PubMed]

14. Frazier, A.L.; Stoneham, S.; Rodriguez-Galindo, C.; Dang, H.; Xia, C.; Olson, T.A.; Murray, M.J.; Amatruda, J.F.; Shaikh, F.; Pashankar, F.; et al. Comparison of carboplatin versus cisplatin in the treatment of paediatric extracranial malignant germ cell tumours: A report of the Malignant Germ Cell International Consortium. Eur. J. Cancer 2018, 98, 30-37. [CrossRef] [PubMed]

15. Lopes, L.F.; Macedo, C.R.P.; Pontes, E.M.; Dos Santos Aguiar, S.; Mastellaro, M.J.; Melaragno, R.; Vianna, S.M.R.; Lopes, P.A.A.; Mendonça, N.; de Assis Almeida, M.T.; et al. Cisplatin and etoposide in childhood germ cell tumor: Brazilian pediatric oncology society protocol GCT-91. J. Clin. Oncol. Off. J. Am. Soc. Clin. Oncol. 2009, 27, 1297-1303. [CrossRef] [PubMed]

16. International germ cell consensus classification: A prognostic factor-based staging system for metastatic germ cell cancers. International Germ Cell Cancer Collaborative Group. J. Clin. Oncol. Off. J. Am. Soc. Clin. Oncol. 1997, 15, 594-603. [CrossRef] 
17. International Prognostic Factors Study Group; Lorch, A.; Beyer, J.; Bascoul-Mollevi, C.; Kramar, A.; Einhorn, L.H.; Necchi, A.; Massard, C.; De Giorgi, U.; Fléchon, A.; et al. Prognostic factors in patients with metastatic germ cell tumors who experienced treatment failure with cisplatin-based first-line chemotherapy. J. Clin. Oncol. Off. J. Am. Soc. Clin. Oncol. 2010, $28,4906-4911$. [CrossRef]

18. Shen, H.; Shih, J.; Hollern, D.P.; Wang, L.; Bowlby, R.; Tickoo, S.K.; Thorsson, V.; Mungall, A.J.; Newton, Y.; Hegde, A.M.; et al. Integrated Molecular Characterization of Testicular Germ Cell Tumors. Cell Rep. 2018, 23, 3392-3406. [CrossRef]

19. Almstrup, K.; Lobo, J.; Mørup, N.; Belge, G.; Rajpert-De Meyts, E.; Looijenga, L.H.J.; Dieckmann, K.-P. Application of miRNAs in the diagnosis and monitoring of testicular germ cell tumours. Nat. Rev. Urol. 2020, 17, 201-213. [CrossRef]

20. Dieckmann, K.-P.; Radtke, A.; Geczi, L.; Matthies, C.; Anheuser, P.; Eckardt, U.; Sommer, J.; Zengerling, F.; Trenti, E.; Pichler, R.; et al. Serum Levels of MicroRNA-371a-3p (M371 Test) as a New Biomarker of Testicular Germ Cell Tumors: Results of a Prospective Multicentric Study. J. Clin. Oncol. Off. J. Am. Soc. Clin. Oncol. 2019, 37, 1412-1423. [CrossRef]

21. Surani, M.A.; Hayashi, K.; Hajkova, P. Genetic and epigenetic regulators of pluripotency. Cell 2007, 128, 747-762. [CrossRef]

22. Runyan, C.; Schaible, K.; Molyneaux, K.; Wang, Z.; Levin, L.; Wylie, C. Steel factor controls midline cell death of primordial germ cells and is essential for their normal proliferation and migration. Development 2006, 133, 4861-4869. [CrossRef]

23. Moch, H.; Cubilla, A.L.; Humphrey, P.A.; Reuter, V.E.; Ulbright, T.M. The 2016 WHO Classification of Tumours of the Urinary System and Male Genital Organs-Part A: Renal, Penile, and Testicular Tumours. Eur. Urol. 2016, 70, 93-105. [CrossRef]

24. Rajpert-De Meyts, E. Developmental model for the pathogenesis of testicular carcinoma in situ: Genetic and environmental aspects. Hum. Reprod. Update 2006, 12, 303-323. [CrossRef]

25. Berney, D.M.; Looijenga, L.H.J.; Idrees, M.; Oosterhuis, J.W.; Rajpert-De Meyts, E.; Ulbright, T.M.; Skakkebaek, N.E. Germ cell neoplasia in situ (GCNIS): Evolution of the current nomenclature for testicular pre-invasive germ cell malignancy. Histopathology 2016, 69, 7-10. [CrossRef]

26. Oram, S.W.; Liu, X.X.; Lee, T.-L.; Chan, W.-Y.; Lau, Y.-F.C. TSPY potentiates cell proliferation and tumorigenesis by promoting cell cycle progression in HeLa and NIH3T3 cells. BMC Cancer 2006, 6, 154. [CrossRef]

27. Stoop, H.; Honecker, F.; van de Geijn, G.J.M.; Gillis, A.J.M.; Cools, M.C.; de Boer, M.; Bokemeyer, C.; Wolffenbuttel, K.P.; Drop, S.L.S.; de Krijger, R.R.; et al. Stem cell factor as a novel diagnostic marker for early malignant germ cells. J. Pathol. 2008, 216, 43-54. [CrossRef] [PubMed]

28. Sperger, J.M.; Chen, X.; Draper, J.S.; Antosiewicz, J.E.; Chon, C.H.; Jones, S.B.; Brooks, J.D.; Andrews, P.W.; Brown, P.O.; Thomson, J.A. Gene expression patterns in human embryonic stem cells and human pluripotent germ cell tumors. Proc. Natl. Acad. Sci. USA 2003, 100, 13350-13355. [CrossRef] [PubMed]

29. Oosterhuis, J.W.; Looijenga, L.H. The biology of human germ cell tumours: Retrospective speculations and new prospectives. Eur. Urol. 1993, 23, 245-250. [CrossRef] [PubMed]

30. Honecker, F.; Stoop, H.; Mayer, F.; Bokemeyer, C.; Castrillon, D.H.; Lau, Y.-F.C.; Looijenga, L.H.J.; Oosterhuis, J.W. Germ cell lineage differentiation in non-seminomatous germ cell tumours. J. Pathol. 2006, 208, 395-400. [CrossRef] [PubMed]

31. Mikuz, G. Spermatocytic seminoma. A tumor with many faces. Der Pathol. 2014, 35, 232-237. [CrossRef]

32. Loveday, C.; Litchfield, K.; Proszek, P.Z.; Cornish, A.J.; Santo, F.; Levy, M.; Macintyre, G.; Holryod, A.; Broderick, P.; Dudakia, D.; et al. Genomic landscape of platinum resistant and sensitive testicular cancers. Nat. Commun. 2020, 11, 2189. [CrossRef] [PubMed]

33. Reuter, V.E. Origins and molecular biology of testicular germ cell tumors. Mod. Pathol. 2005, 18, S51-S60. [CrossRef] [PubMed]

34. Kernek, K.M.; Brunelli, M.; Ulbright, T.M.; Eble, J.N.; Martignoni, G.; Zhang, S.; Michael, H.; Cummings, O.W.; Cheng, L. Fluorescence in situ hybridization analysis of chromosome 12p in paraffin-embedded tissue is useful for establishing germ cell origin of metastatic tumors. Mod. Pathol. 2004, 17, 1309-1313. [CrossRef] [PubMed]

35. Cheng, L.; Zhang, S.; MacLennan, G.T.; Poulos, C.K.; Sung, M.-T.; Beck, S.D.; Foster, R.S. Interphase Fluorescence In Situ Hybridization Analysis of Chromosome 12p Abnormalities Is Useful for Distinguishing Epidermoid Cysts of the Testis from Pure Mature Teratoma. Clin. Cancer Res. 2006, 12, 5668-5672. [CrossRef]

36. McIntyre, A.; Summersgill, B.; Spendlove, H.E.; Huddart, R.; Houlston, R.; Shipley, J. Activating mutations and/or expression levels of tyrosine kinase receptors GRB7, RAS, and BRAF in testicular germ cell tumors. Neoplasia 2005, 7, 1047-1052. [CrossRef] [PubMed]

37. Goddard, N.C.; McIntyre, A.; Summersgill, B.; Gilbert, D.; Kitazawa, S.; Shipley, J. KIT and RAS signalling pathways in testicular germ cell tumours: New data and a review of the literature. Int. J. Androl. 2007, 30, 337-349. [CrossRef]

38. Summersgill, B.; Goker, H.; Weber-Hall, S.; Huddart, R.; Horwich, A.; Shipley, J. Molecular cytogenetic analysis of adult testicular germ cell tumours and identification of regions of consensus copy number change. Br. J. Cancer 1998, 77, 305-313. [CrossRef]

39. Litchfield, K.; Summersgill, B.; Yost, S.; Sultana, R.; Labreche, K.; Dudakia, D.; Renwick, A.; Seal, S.; Al-Saadi, R.; Broderick, P.; et al. Whole-exome sequencing reveals the mutational spectrum of testicular germ cell tumours. Nat. Commun. 2015, 6, 5973. [CrossRef]

40. Mostert, M.; Rosenberg, C.; Stoop, H.; Schuyer, M.; Timmer, A.; Oosterhuis, W.; Looijenga, L. Comparative Genomic and In Situ Hybridization of Germ Cell Tumors of the Infantile Testis. Lab. Investig. 2000, 80, 1055-1064. [CrossRef]

41. Perlman, E.J.; Hu, J.; Ho, D.; Cushing, B.; Lauer, S.; Castleberry, R.P. Genetic Analysis of Childhood Endodermal Sinus Tumors by Comparative Genomic Hybridization. J. Pediatric Hematol. Oncol. 2000, 22, 100-105. [CrossRef] 
42. Schneider, D.T.; Schuster, A.E.; Fritsch, M.K.; Calaminus, G.; Göbel, U.; Harms, D.; Lauer, S.; Olson, T.; Perlman, E.J. Genetic analysis of mediastinal nonseminomatous germ cell tumors in children and adolescents. Geneschromosomes Cancer 2002, 34, 115-125. [CrossRef]

43. Palmer, R.D.; Foster, N.A.; Vowler, S.L.; Roberts, I.; Thornton, C.M.; Hale, J.P.; Schneider, D.T.; Nicholson, J.C.; Coleman, N. Malignant germ cell tumours of childhood: New associations of genomic imbalance. Br. J. Cancer 2007, 96, 667-676. [CrossRef]

44. Vladušić, T.; Hrašćan, R.; Vrhovac, I.; Krušlin, B.; Gamulin, M.; Grgić, M.; Pećina-Šlaus, N.; Čolić, J.F. Loss of heterozygosity of selected tumor suppressor genes in human testicular germ cell tumors. Pathol. Res. Pract. 2010, 206, 163-167. [CrossRef] [PubMed]

45. Vladusic, T.; Hrascan, R.; Pecina-Slaus, N.; Vrhovac, I.; Gamulin, M.; Franekic, J.; Kruslin, B. Loss of heterozygosity of CDKN2A (p16INK4a) and RB1 tumor suppressor genes in testicular germ cell tumors. Radiol. Oncol. 2010, 44. [CrossRef]

46. Miyai, K.; Ito, K.; Nakanishi, K.; Tsuda, H. Seminoma component of mixed testicular germ cell tumor shows a higher incidence of loss of heterozygosity than pure-type seminoma. Hum. Pathol. 2019, 84, 71-80. [CrossRef]

47. Peng, H.Q.; Hogg, D.; Malkin, D.; Bailey, D.; Gallie, B.L.; Bulbul, M.; Jewett, M.; Buchanan, J.; Goss, P.E. Mutations of the p53 gene do not occur in testis cancer. Cancer Res. 1993, 53, 3574-3578. [PubMed]

48. Houldsworth, J.; Xiao, H.; Murty, V.; Chen, W.; Ray, B.; Reuter, V.E.; Bosl, G.J.; Chaganti, R. Human male germ cell tumor resistance to cisplatin is linked to TP53 gene mutation. Oncogene 1998, 16, 2345-2349. [CrossRef] [PubMed]

49. Boublikova, L.; Buchler, T.; Stary, J.; Abrahamova, J.; Trka, J. Molecular biology of testicular germ cell tumors: Unique features awaiting clinical application. Crit. Rev. Oncol. Hematol. 2014, 89, 366-385. [CrossRef] [PubMed]

50. Taylor-Weiner, A.; Zack, T.; O’Donnell, E.; Guerriero, J.L.; Bernard, B.; Reddy, A.; Han, G.C.; AlDubayan, S.; Amin-Mansour, A.; Schumacher, S.E.; et al. Genomic evolution and chemoresistance in germ-cell tumours. Nature 2016, 540, 114-118. [CrossRef]

51. Kersemaekers, A.-M.F.; Mayer, F.; Molier, M.; van Weeren, P.C.; Oosterhuis, J.W.; Bokemeyer, C.; Looijenga, L.H.J. Role of P53 and MDM2 in treatment response of human germ cell tumors. J. Clin. Oncol. Off. J. Am. Soc. Clin. Oncol. 2002, 20, $1551-1561$. [CrossRef]

52. Bagrodia, A.; Lee, B.H.; Lee, W.; Cha, E.K.; Sfakianos, J.P.; Iyer, G.; Pietzak, E.J.; Gao, S.P.; Zabor, E.C.; Ostrovnaya, I.; et al. Genetic Determinants of Cisplatin Resistance in Patients with Advanced Germ Cell Tumors. J. Clin. Oncol. Off. J. Am. Soc. Clin. Oncol. 2016, 34, 4000-4007. [CrossRef] [PubMed]

53. Lafin, J.T.; Bagrodia, A.; Woldu, S.; Amatruda, J.F. New insights into germ cell tumor genomics. Andrology 2019, 7, 507-515. [CrossRef] [PubMed]

54. Feldman, D.R.; Iyer, G.; Van Alstine, L.; Patil, S.; Al-Ahmadie, H.; Reuter, V.E.; Bosl, G.J.; Chaganti, R.S.; Solit, D.B. Presence of Somatic Mutations within PIK3CA, AKT, RAS, and FGFR3 but not BRAF in Cisplatin-Resistant Germ Cell Tumors. Clin. Cancer Res. 2014, 20, 3712-3720. [CrossRef]

55. Cutcutache, I.; Suzuki, Y.; Tan, I.B.; Ramgopal, S.; Zhang, S.; Ramnarayanan, K.; Gan, A.; Lee, H.H.; Tay, S.T.; Ooi, A.; et al. Exome-Wide Sequencing Shows Low Mutation Rates and Identifies Novel Mutated Genes in Seminomas. Eur. Urol. 2015, 68, 77-83. [CrossRef] [PubMed]

56. Kemmer, K.; Corless, C.L.; Fletcher, J.A.; McGreevey, L.; Haley, A.; Griffith, D.; Cummings, O.W.; Wait, C.; Town, A.; Heinrich, M.C. KIT mutations are common in testicular seminomas. Am. J. Pathol. 2004, 164, 305-313. [CrossRef]

57. Mata, D.A.; Yang, S.-R.; Ferguson, D.C.; Liu, Y.; Sharma, R.; Benhamida, J.K.; Al-Ahmadie, H.A.; Chakravarty, D.; Solit, D.B.; Tickoo, S.K.; et al. RAS/MAPK Pathway Driver Alterations Are Significantly Associated with Oncogenic KIT Mutations in Germ-Cell Tumors. Urology 2020, 144, 111-116. [CrossRef]

58. Colicelli, J. Human RAS Superfamily Proteins and Related GTPases. Sci. Signal. 2004, 2004, re13. [CrossRef]

59. Simanshu, D.K.; Nissley, D.V.; McCormick, F. RAS Proteins and Their Regulators in Human Disease. Cell 2017, 170, 17-33. [CrossRef]

60. Kodaz, H. Frequency of RAS Mutations (KRAS, NRAS, HRAS) in Human Solid Cancer. Eurasian J. Med. Oncol. 2017. [CrossRef]

61. Woldu, S.L.; Amatruda, J.F.; Bagrodia, A. Testicular germ cell tumor genomics. Curr. Opin. Urol. 2017, 27, 41-47. [CrossRef]

62. Masqué-Soler, N.; Szczepanowski, M.; Leuschner, I.; Vokuhl, C.; Haag, J.; Calaminus, G.; Klapper, W. Absence of BRAF mutation in pediatric and adolescent germ cell tumors indicate biological differences to adult tumors. Pediatric Blood Cancer 2012, 59, 732-735. [CrossRef]

63. Cárcano, F.M.; Lengert, A.H.; Vidal, D.O.; Scapulatempo Neto, C.; Queiroz, L.; Marques, H.; Baltazar, F.; Berardinelli, G.N.; Martinelli, C.M.S.; da Silva, E.C.A.; et al. Absence of microsatellite instability and BRAF (V600E) mutation in testicular germ cell tumors. Andrology 2016, 4, 866-872. [CrossRef]

64. Cárcano, F.M.; Vidal, D.O.; van Helvoort Lengert, A.; Neto, C.S.; Queiroz, L.; Marques, H.; Baltazar, F.; da Silva Martinelli, C.M.; Soares, P.; da Silva, E.C.A.; et al. Hotspot TERT promoter mutations are rare events in testicular germ cell tumors. Tumor Biol. 2016, 37, 4901-4907. [CrossRef] [PubMed]

65. Lobo, J.; Gillis, A.; Jerónimo, C.; Henrique, R.; Looijenga, L. Human Germ Cell Tumors are Developmental Cancers: Impact of Epigenetics on Pathobiology and Clinic. Int. J. Mol. Sci. 2019, 20, 258. [CrossRef] [PubMed]

66. Smiraglia, D.J.; Szymanska, J.; Kraggerud, S.M.; Lothe, R.A.; Peltomäki, P.; Plass, C. Distinct epigenetic phenotypes in seminomatous and nonseminomatous testicular germ cell tumors. Oncogene 2002, 21, 3909-3916. [CrossRef] [PubMed]

67. Okamoto, K. Epigenetics: A way to understand the origin and biology of testicular germ cell tumors. Int. J. Urol. 2012, 19, 504-511. [CrossRef] 
68. Almstrup, K.; Nielsen, J.E.; Mlynarska, O.; Jansen, M.T.; Jørgensen, A.; Skakkebæk, N.E.; Rajpert-De Meyts, E. Carcinoma in situ testis displays permissive chromatin modifications similar to immature foetal germ cells. Br. J. Cancer 2010, 103, $1269-1276$. [CrossRef] [PubMed]

69. Da Silva Martinelli, C.M.; Van Helvoort Lengert, A.; Cárcano, F.M.; Silva, E.C.A.; Brait, M.; Lopes, L.F.; Vidal, D.O. MGMT and CALCA promoter methylation are associated with poor prognosis in testicular germ cell tumor patients. Oncotarget 2017, 8, 50608-50617. [CrossRef]

70. Koul, S.; Houldsworth, J.; Mansukhani, M.M.; Donadio, A.; McKiernan, J.M.; Reuter, V.E.; Bosl, G.J.; Chaganti, R.S.; Murty, V. V Characteristic promoter hypermethylation signatures in male germ cell tumors. Mol. Cancer 2002, 1, 8. [CrossRef]

71. Koul, S.; McKiernan, J.M.; Narayan, G.; Houldsworth, J.; Bacik, J.; Dobrzynski, D.L.; Assaad, A.M.; Mansukhani, M.; Reuter, V.E.; Bosl, G.J.; et al. Role of promoter hypermethylation in Cisplatin treatment response of male germ cell tumors. Mol. Cancer 2004, 3, 16. [CrossRef] [PubMed]

72. Spiller, C.M.; Gillis, A.J.M.; Burnet, G.; Stoop, H.; Koopman, P.; Bowles, J.; Looijenga, L.H.J. Cripto: Expression, epigenetic regulation and potential diagnostic use in testicular germ cell tumors. Mol. Oncol. 2016, 10, 526-537. [CrossRef]

73. Kawakami, T.; Okamoto, K.; Ogawa, O.; Okada, Y. XIST unmethylated DNA fragments in male-derived plasma as a tumour marker for testicular cancer. Lancet 2004, 363, 40-42. [CrossRef]

74. Kato, N.; Tamura, G.; Fukase, M.; Shibuya, H.; Motoyama, T. Hypermethylation of the RUNX3 Gene Promoter in Testicular Yolk Sac Tumor of Infants. Am. J. Pathol. 2003, 163, 387-391. [CrossRef]

75. Kato, N.; Shibuya, H.; Fukase, M.; Tamura, G.; Motoyama, T. Involvement of adenomatous polyposis coli (APC) gene in testicular yolk sac tumor of infants. Hum. Pathol. 2006, 37, 48-53. [CrossRef] [PubMed]

76. Mirabello, L.; Savage, S.A.; Korde, L.; Gadalla, S.M.; Greene, M.H. LINE-1 methylation is inherited in familial testicular cancer kindreds. BMC Med. Genet. 2010, 11, 77. [CrossRef]

77. Williams, L.A.; Mills, L.; Hooten, A.J.; Langer, E.; Roesler, M.; Frazier, A.L.; Krailo, M.; Nelson, H.H.; Bestrashniy, J.; Amatruda, J.F.; et al. Differences in DNA methylation profiles by histologic subtype of paediatric germ cell tumours: A report from the Children's Oncology Group. Br. J. Cancer 2018, 119, 864-872. [CrossRef]

78. Ambros, V. The functions of animal microRNAs. Nature 2004, 431, 350-355. [CrossRef]

79. Bartel, D.P. MicroRNAs: Genomics, biogenesis, mechanism, and function. Cell 2004, 116, 281-297. [CrossRef]

80. Huang, Y.; Shen, X.J.; Zou, Q.; Wang, S.P.; Tang, S.M.; Zhang, G.Z. Biological functions of microRNAs: A review. J. Physiol. Biochem. 2011, 67, 129-139. [CrossRef] [PubMed]

81. Lewis, B.P.; Burge, C.B.; Bartel, D.P. Conserved seed pairing, often flanked by adenosines, indicates that thousands of human genes are microRNA targets. Cell 2005, 120, 15-20. [CrossRef] [PubMed]

82. Voorhoeve, P.M.; le Sage, C.; Schrier, M.; Gillis, A.J.M.; Stoop, H.; Nagel, R.; Liu, Y.-P.; van Duijse, J.; Drost, J.; Griekspoor, A.; et al. A genetic screen implicates miRNA-372 and miRNA-373 as oncogenes in testicular germ cell tumors. Cell 2006, 124, $1169-1181$. [CrossRef] [PubMed]

83. Palmer, R.D.; Murray, M.J.; Saini, H.K.; van Dongen, S.; Abreu-Goodger, C.; Muralidhar, B.; Pett, M.R.; Thornton, C.M.; Nicholson, J.C.; Enright, A.J.; et al. Malignant Germ Cell Tumors Display Common MicroRNA Profiles Resulting in Global Changes in Expression of Messenger RNA Targets. Cancer Res. 2010, 70, 2911-2923. [CrossRef] [PubMed]

84. Murray, M.J.; Halsall, D.J.; Hook, C.E.; Williams, D.M.; Nicholson, J.C.; Coleman, N. Identification of MicroRNAs from the miR-371 373 and miR-302 Clusters as Potential Serum Biomarkers of Malignant Germ Cell Tumors. Am. J. Clin. Pathol. 2011, 135, 119-125. [CrossRef] [PubMed]

85. Badia, R.R.; Abe, D.; Wong, D.; Singla, N.; Savelyeva, A.; Chertack, N.; Woldu, S.L.; Lotan, Y.; Mauck, R.; Ouyang, D.; et al. Real-World Application of Pre-Orchiectomy miR-371a-3p Test in Testicular Germ Cell Tumor Management. J. Urol. 2021, 205, 137-144. [CrossRef] [PubMed]

86. Port, M.; Glaesener, S.; Ruf, C.; Riecke, A.; Bokemeyer, C.; Meineke, V.; Honecker, F.; Abend, M. Micro-RNA expression in cisplatin resistant germ cell tumor cell lines. Mol. Cancer 2011, 10, 52. [CrossRef] [PubMed]

87. Piulats, J.M.; Vidal, A.; Villanueva, A.; Muñoz, C.; Pisa, A.; Nadal, M.; Germa-Lluch, J.R.; Condom, E.; del Muro, X.G. MLH1 and BRAF status analysis in metastatic germ cell tumors. J. Clin. Oncol. 2010, 28, e15092. [CrossRef]

88. Satpute, S.R.; Koster, R.; Nathanson, K.L.; Vaughn, D.J.; Albany, C.; Einhorn, L.H.; Hanna, N.H. Retrospective, correlative study of BRAF mutation V600E in testicular cancer patients. J. Clin. Oncol. 2013, 31, e15584. [CrossRef]

89. Lerro, C.C.; Robbins, A.S.; Fedewa, S.A.; Ward, E.M. Disparities in stage at diagnosis among adults with testicular germ cell tumors in the National Cancer Data Base. Urol. Oncol. Semin. Orig. Investig. 2014, 32, 23.e15. [CrossRef]

90. Piulats, J.M.; Jiménez, L.; García del Muro, X.; Villanueva, A.; Viñals, F.; Germà-Lluch, J.R. Molecular mechanisms behind the resistance of cisplatin in germ cell tumours. Clin. Transl. Oncol. 2009, 11, 780-786. [CrossRef]

91. Jacobsen, C.; Honecker, F. Cisplatin resistance in germ cell tumours: Models and mechanisms. Andrology 2015, 3, 111-121. [CrossRef]

92. Oosterhuis, J.W.; Andrews, P.W.; Knowles, B.B.; Damjanov, I. Effects ofCIS-platinum on embryonal carcinoma cell linesin vitro. Int. J. Cancer 1984, 34, 133-139. [CrossRef]

93. Cairns, J. Somatic stem cells and the kinetics of mutagenesis and carcinogenesis. Proc. Natl. Acad. Sci. USA 2002, 99, 10567-10570. [CrossRef] [PubMed] 
94. Hong, Y.; Stambrook, P.J. Restoration of an absent G1 arrest and protection from apoptosis in embryonic stem cells after ionizing radiation. Proc. Natl. Acad. Sci. USA 2004, 101, 14443-14448. [CrossRef] [PubMed]

95. Mayer, F.; Gillis, A.J.M.; Dinjens, W.; Oosterhuis, J.W.; Bokemeyer, C.; Looijenga, L.H.J. Microsatellite instability of germ cell tumors is associated with resistance to systemic treatment. Cancer Res. 2002, 62, 2758-2760.

96. Looijenga, L.H.J.; Stoop, H.; de Leeuw, H.P.J.C.; de Gouveia Brazao, C.A.; Gillis, A.J.M.; van Roozendaal, K.E.P.; van Zoelen, E.J.J.; Weber, R.F.A.; Wolffenbuttel, K.P.; van Dekken, H.; et al. POU5F1 (OCT3/4) identifies cells with pluripotent potential in human germ cell tumors. Cancer Res. 2003, 63, 2244-2250.

97. Hart, A.H.; Hartley, L.; Parker, K.; Ibrahim, M.; Looijenga, L.H.J.; Pauchnik, M.; Chow, C.W.; Robb, L. The pluripotency homeobox gene NANOG is expressed in human germ cell tumors. Cancer 2005, 104, 2092-2098. [CrossRef]

98. Singh, R.; Fazal, Z.; Corbet, A.K.; Bikorimana, E.; Rodriguez, J.C.; Khan, E.M.; Shahid, K.; Freemantle, S.J.; Spinella, M.J. Epigenetic Remodeling through Downregulation of Polycomb Repressive Complex 2 Mediates Chemotherapy Resistance in Testicular Germ Cell Tumors. Cancers 2019, 11, 796. [CrossRef]

99. Lobo, J.; Jerónimo, C.; Henrique, R. Cisplatin Resistance in Testicular Germ Cell Tumors: Current Challenges from Various Perspectives. Cancers 2020, 12, 1601. [CrossRef]

100. Bakardjieva-Mihaylova, V.; Skvarova Kramarzova, K.; Slamova, M.; Svaton, M.; Rejlova, K.; Zaliova, M.; Dobiasova, A.; Fiser, K.; Stuchly, J.; Grega, M.; et al. Molecular Basis of Cisplatin Resistance in Testicular Germ Cell Tumors. Cancers 2019, $11,1316$. [CrossRef]

101. Schmidtova, S.; Kalavska, K.; Kucerova, L. Molecular Mechanisms of Cisplatin Chemoresistance and Its Circumventing in Testicular Germ Cell Tumors. Curr. Oncol. Rep. 2018, 20, 88. [CrossRef] [PubMed]

102. Piulats, J.M.; Vidal, A.; García-Rodríguez, F.J.; Muñoz, C.; Nadal, M.; Moutinho, C.; Martínez-Iniesta, M.; Mora, J.; Figueras, A.; Guinó, E.; et al. Orthoxenografts of Testicular Germ Cell Tumors Demonstrate Genomic Changes Associated with Cisplatin Resistance and Identify PDMP as a Resensitizing Agent. Clin. Cancer Res. 2018, 24, 3755-3766. [CrossRef]

103. Wilding, J.L.; Bodmer, W.F. Cancer cell lines for drug discovery and development. Cancer Res. 2014, 74, 2377-2384. [CrossRef] [PubMed]

104. Cook, N.; Jodrell, D.I.; Tuveson, D.A. Predictive in vivo animal models and translation to clinical trials. Drug Discov. Today 2012, 17, 253-260. [CrossRef]

105. Tentler, J.J.; Tan, A.C.; Weekes, C.D.; Jimeno, A.; Leong, S.; Pitts, T.M.; Arcaroli, J.J.; Messersmith, W.A.; Eckhardt, S.G. Patientderived tumour xenografts as models for oncology drug development. Nat. Rev. Clin. Oncol. 2012, 9, 338-350. [CrossRef] [PubMed]

106. Kameya, T.; Shimosato, Y.; Tumuraya, M.; Ohsawa, N.; Nomura, T. Human Gastric Choriocarcinoma Serially Transplanted in Nude Mice2. J. Natl. Cancer Inst. 1976, 56, 325-332. [CrossRef] [PubMed]

107. Shimosato, Y.; Kameya, T.; Nagai, K.; Hirohashi, S.; Koide, T.; Hayashi, H.; Nomura, T. Transplantation of Human Tumors in Nude Mice23. J. Natl. Cancer Inst. 1976, 56, 1251-1260. [CrossRef]

108. Mueller, T.; Mueller, L.P.; Holzhausen, H.-J.; Witthuhn, R.; Albers, P.; Schmoll, H.-J. Histological evidence for the existence of germ cell tumor cells showing embryonal carcinoma morphology but lacking OCT4 expression and cisplatin sensitivity. Histochem. Cell Biol. 2010, 134, 197-204. [CrossRef] [PubMed]

109. Schmidtova, S.; Kalavska, K.; Gercakova, K.; Cierna, Z.; Miklikova, S.; Smolkova, B.; Buocikova, V.; Miskovska, V.; Durinikova, E.; Burikova, M.; et al. Disulfiram Overcomes Cisplatin Resistance in Human Embryonal Carcinoma Cells. Cancers 2019, 11, 1224. [CrossRef]

110. Pierpont, T.M.; Lyndaker, A.M.; Anderson, C.M.; Jin, Q.; Moore, E.S.; Roden, J.L.; Braxton, A.; Bagepalli, L.; Kataria, N.; Hu, H.Z.; et al. Chemotherapy-Induced Depletion of OCT4-Positive Cancer Stem Cells in a Mouse Model of Malignant Testicular Cancer. Cell Rep. 2017, 21, 1896-1909. [CrossRef] [PubMed]

111. Schaffrath, J.; Schmoll, H.-J.; Voigt, W.; Müller, L.P.; Müller-Tidow, C.; Mueller, T. Efficacy of targeted drugs in germ cell cancer cell lines with differential cisplatin sensitivity. PLOS ONE 2017, 12, e0178930. [CrossRef]

112. Hanahan, D.; Weinberg, R.A. Hallmarks of cancer: The next generation. Cell 2011, 144, 646-674. [CrossRef] [PubMed] 